\title{
Twenty-one years of mass balance observations along the K-transect, West Greenland
}

\author{
R. S. W. van de Wal, W. Boot, C. J. P. P. Smeets, H. Snellen, M. R. van den Broeke, and J. Oerlemans \\ Institute for Marine and Atmospheric research Utrecht, Utrecht University, The Netherlands
}

Correspondence to: R. S. W. van de Wal (r.s.w.vandewal@uu.nl)

Received: 6 April 2012 - Published in Earth Syst. Sci. Data Discuss.: 14 May 2012

Revised: 20 July 2012 - Accepted: 26 July 2012 - Published: 29 August 2012

\begin{abstract}
A 21-yr record is presented of surface mass balance measurements along the K-transect. The series covers the period 1990-2011. Data are available at eight sites along a transect over an altitude range of $380-1850 \mathrm{~m}$ at approximately $67^{\circ} \mathrm{N}$ in West Greenland. The surface mass balance gradient is on average $3.8 \times 10^{-3} \mathrm{~m}$ w.e. $\mathrm{m}^{-1}$, and the mean equilibrium line altitude is $1553 \mathrm{~m}$ a.s.l. Only the lower three sites within $10 \mathrm{~km}$ of the margin up to an elevation of $700 \mathrm{~m}$ experience a significant increasing trend in the ablation over the entire period. Data are available at: doi:10.1594/PANGAEA.779181.
\end{abstract}

\section{Introduction}

Over the last $10 \mathrm{yr}$, our understanding of the mass balance of the Greenland ice sheet has improved considerably due to satellite observations. The analysis of gravity field, radar altimetry and interferometry data combined with regional climate models has contributed to this (e.g. Rignot and Kanagaratnam, 2006; Thomas et al., 2008; Wouters et al., 2008; Van den Broeke et al., 2009). Longer records of the surface mass balance are sparse, in particular for the ablation region. Here we present a compilation of data from ground observations as measured along the K-transect over the last $21 \mathrm{yr}$. Figure 1 shows the K-transect where 21 yr ago IMAU (Institute for Marine and Atmospheric research Utrecht) started with mass balance observations, GPS measurements and later observations by automatic weather stations. It is the longest record of ground-based surface mass balance measurements in Greenland. Several short series of observations exist (e.g. Thomsen, 1987; Braithwaite and Olesen, 1989; Reeh, 1991; Van As et al., 2011), but they are all temporally limited in length. Nevertheless, those data are important because they are located in widely different climatological regions.

The paper is an update of the work presented by van de Wal et al. (1996, 2005) and Greuell et al. (2001) who presented mass balance data covering shorter periods. Combined with the weather station data, these data have also been used for several validation studies of mass balance models. An overview of the weather station data has been presented by Van den Broeke et al. (2008a, b, 2011). Here we present the surface mass balance data and discuss the spatial and temporal pattern.

\section{Surface mass balance measurements}

Eight sites are visited for mass balance measurements and redrilling of stakes every year, mostly in late August. Six sites are located in the ablation area, one near the equilibrium line altitude and one in the accumulation zone. The record for the highest site is $4 \mathrm{yr}$ shorter, and some values are averaged over $2 \mathrm{yr}$ because visits to the site failed several times due to logistical constraints. At each site, at least two stakes are maintained throughout the entire period. Data shown in Table 1 and in the figures are the mean values of the individual stake readings and always represent one mass balance season. Data are not reduced to a fixed date, but measurements are usually carried out in late August. An exception to this rule is the mass balance year 2009-2010 which showed a significant melt in autumn 2010. Based on sonic height ranger data at S5, S6 and S9, we reconstructed the autumn 2010 melt, subtracted this from 2010-2011, and added this to the mass balance year 2009-2010. This correction ranges from $90 \mathrm{~cm}$ w.e. at $\mathrm{S} 4$ to $19 \mathrm{~cm}$ w.e. at $\mathrm{S} 9$. Length changes are 


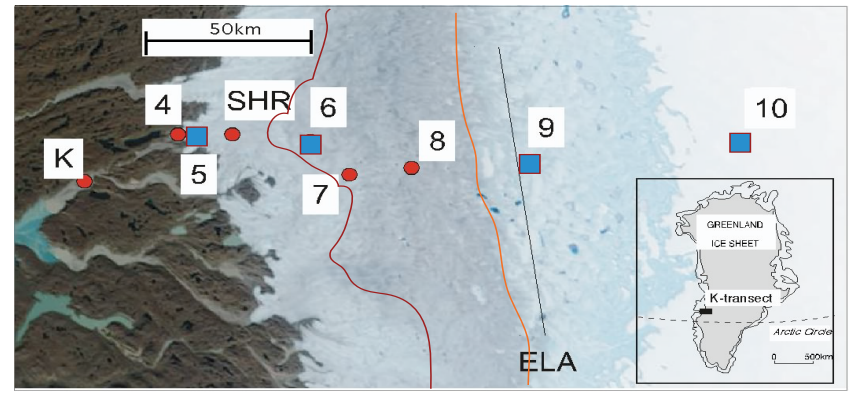

Figure 1. The K-transect in West Greenland. $\mathrm{K}$ is Kangerlussuaq. The sites 4, 5, SHR, 6, 7, 8, 9 and 10 are mass balance sites. The blue squares indicate the position of the IMAU weather stations. The equilibrium line altitude is located close to Site 9 . The two coloured lines indicate the dark zone where albedo is lower than in the surrounding areas (Wientjes and Oerlemans, 2010; Wientjes et al., 2011). Background is a true colour composition of NASA Modis/Terra from 26 August 2003.

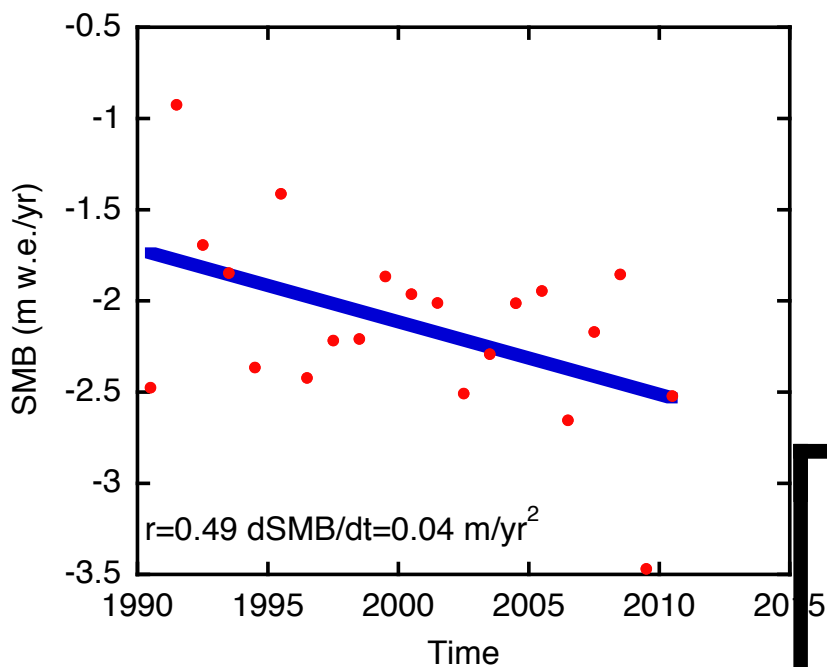

Figure 2. The surface mass balance averaged (S4-S9) over the transect as a function of time. $\mathrm{dSMB} / \mathrm{dt}$ is the gradient in the surface mass balance, blue line derived from linear regression.

converted to surface mass balance by assuming an ice density of $900 \mathrm{~kg} \mathrm{~m}^{-3}$, except at the highest site where snow and firn is at the surface. There density measurements are carried out. Sites near the margin have been relocated a few times because of crevasse zones and data at the lowest two sites are therefore reduced to a fixed elevation. The mass balance data for the other sites are not corrected for the small height differences due to ice flow or stake replacement. The largest uncertainty in the measurements in the lower region (S4, S5, SHR) is caused by the rough surface topography. It is estimated that annual values at these sites have an uncertainty $(1 \sigma)$ of $20 \mathrm{~cm}$ w.e. Ignoring other systematic uncertainties, this implies a negligible error for the annual average over the entire transect as it is based on data from seven sites.
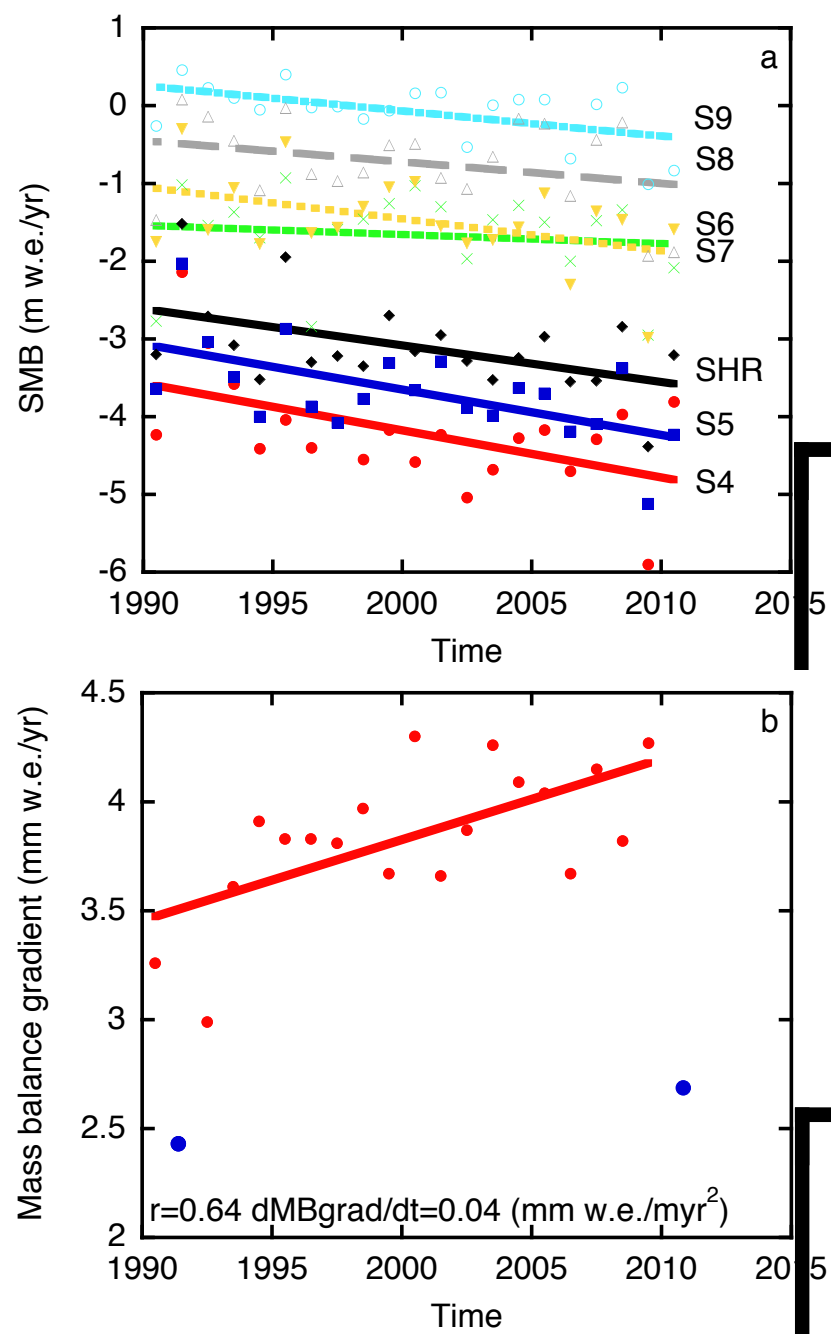

Figure 3. (a) Temporal evolution of the individual surface mass balance sites. Ablation increases over time only near the margin of the ice sheet. Dotted lines are sites higher on the transect with no significant trend over time. (b) The mass balance gradient as a function of time. Blue dots are years excluded from the regression analysis as explained in the text.

\subsection{Mass balance as a function of time}

Figure 2 shows the interannual variability of the average mass balance along the transect. Every site has been given an equal weight, and Site 10 has been neglected because the record is incomplete. Weighing the records proportional to the distance between the neighbouring points yields a similar variability but on average less ablation because the higher points cover larger areas (van de Wal et al., 2005). The trend in the observation is small $\left(0.04 \mathrm{~m} \mathrm{yr}^{-2}\right)$ and barely significant $(r=0.49)$, and the highest ablation took place in 2010 (Tedesco et al., 2011).

It has been argued that satellite elevation changes for Greenland (e.g. Krabill et al., 2004) indicate that the marginal areas of Greenland were thinning and the central 
Table 1. Surface mass balance measurements (in mw.e.) along the K-transect at $67^{\circ} \mathrm{N}$. Distances are presented in kilometres from the western ice margin. Values at S4 are recalculated to a height of $383 \mathrm{~m}$ a.s.l. Bold values are outside the $2 \sigma$ interval with respect to the $20 \mathrm{yr}$ mean (1990-2010) and standard deviation.

\begin{tabular}{|c|c|c|c|c|c|c|c|c|}
\hline & $\begin{array}{r}\text { Site } 4 \\
383 \\
\text { (m a.s.l.) } \\
3 \mathrm{~km}\end{array}$ & $\begin{array}{r}\text { Site } 5 \\
490 \\
\text { (m a.s.1.) } \\
6 \mathrm{~km}\end{array}$ & $\begin{array}{r}\text { SHR } \\
710 \\
\text { (m a.s.1.) } \\
14 \mathrm{~km}\end{array}$ & $\begin{array}{r}\text { Site } 6 \\
1010 \\
\text { (m a.s.1.) } \\
37 \mathrm{~km}\end{array}$ & $\begin{array}{r}\text { Site } 7 \\
1110 \\
\text { (m a.s.1.) } \\
52 \mathrm{~km}\end{array}$ & $\begin{array}{r}\text { Site } 8 \\
1260 \\
\text { (m a.s.1.) } \\
63 \mathrm{~km}\end{array}$ & $\begin{array}{r}\text { Site } 9 \\
1520 \\
\text { (m a.s.1.) } \\
91 \mathrm{~km}\end{array}$ & $\begin{array}{c}\text { Site } 10 \\
1850 \\
\text { (m a.s.l.) } \\
143 \mathrm{~km}\end{array}$ \\
\hline 1990-1991 & -4.23 & -3.64 & -3.20 & -2.77 & -1.75 & -1.47 & -0.26 & \\
\hline 1991-1992 & -2.14 & -2.03 & -1.52 & -1.02 & -0.30 & 0.08 & 0.46 & \\
\hline 1992-1993 & -3.05 & -3.04 & -2.71 & -1.54 & -1.60 & -0.14 & 0.23 & \\
\hline 1993-1994 & -3.58 & -3.49 & -3.08 & -1.37 & -1.06 & -0.45 & 0.10 & \\
\hline 1994-1995 & -4.41 & -4.00 & -3.52 & -1.70 & -1.78 & -1.09 & -0.05 & 0.01 \\
\hline 1995-1996 & -4.04 & -2.87 & -1.95 & -0.93 & -0.47 & -0.03 & 0.40 & 0.49 \\
\hline 1996-1997 & -4.40 & -3.87 & -3.30 & -2.84 & -1.64 & -0.88 & -0.02 & 0.27 \\
\hline 1997-1998 & -4.08 & -4.08 & -3.22 & -1.59 & -1.57 & -0.97 & -0.01 & 0.29 \\
\hline 1998-1999 & -4.55 & -3.77 & -3.35 & -1.46 & -1.30 & -0.86 & -0.17 & 0.06 \\
\hline 1999-2000 & -4.17 & -3.31 & -2.70 & -1.26 & -1.05 & -0.51 & -0.06 & 0.26 \\
\hline 2000-2001 & -4.58 & -3.66 & -3.16 & -1.03 & -0.98 & -0.49 & 0.16 & 0.57 \\
\hline 2001-2002 & -4.23 & -3.29 & -2.95 & -1.30 & -1.55 & -0.93 & 0.17 & 0.29 \\
\hline 2002-2003 & -5.04 & -3.89 & -3.29 & -1.97 & -1.77 & -1.07 & -0.53 & 0.11 \\
\hline 2003-2004 & -4.68 & -3.99 & -3.53 & -1.47 & -1.73 & -0.66 & 0.01 & 0.45 \\
\hline 2004-2005 & -4.28 & -3.63 & -3.24 & -1.28 & -1.57 & -0.17 & 0.08 & 0.45 \\
\hline 2005-2006 & -4.17 & -3.70 & -2.97 & -1.50 & -1.13 & -0.23 & 0.08 & 0.39 \\
\hline 2006-2007 & -4.7 & -4.19 & -3.55 & -2.00 & -2.30 & -1.16 & -0.68 & 0.04 \\
\hline 2007-2008 & -4.29 & -4.10 & -3.54 & -1.48 & -1.36 & -0.44 & 0.02 & 0.21 \\
\hline 2008-2009 & -3.97 & -3.38 & -2.84 & -1.34 & -1.47 & -0.22 & 0.23 & 0.20 \\
\hline 2009-2010 & -5.9 & -5.12 & -4.39 & -2.95 & -2.99 & -1.93 & -1.01 & 0.20 \\
\hline Mean 90-10 & -4.22 & -3.65 & -3.10 & -1.58 & -1.45 & -0.64 & -0.03 & 0.27 \\
\hline standard deviation & 0.76 & 0.63 & 0.62 & 0.54 & 0.60 & 0.50 & 0.36 & 0.17 \\
\hline 2010-2011 & -3.81 & -4.23 & -3.21 & -2.08 & -1.59 & -1.89 & -0.84 & \\
\hline
\end{tabular}

parts were thickening over the period 1993-2003. This finding was based on measurement intervals from 1993-1998, 1997-2001, 1997-2002 and 2002-2003. If we consider the trend in the mass balance for the individual sites as shown in Fig. 3a, we can confirm that the ablation near the margin (S4, S5, SHR) increases over time. Reproducing the analysis to the identical four periods as Krabill et al. (2004) used shows that over the last period, which is the mass balance year 2002-2003, the ablation is indeed larger than during the other three periods. So although a strict comparison of the finding by Krabill et al. (2004) is not convincing due to the limited temporal coverage, the increased thinning near the margins as presented by Krabill et al. (2004) is confirmed by the enhanced ablation over the entire period in the lower ablation zone. More recently, several papers (e.g. Sørensen et al., 2011; Zwally et al., 2011) confirmed the marginal thinning more convincingly based on several independent techniques to estimate mass change.

The increase in ablation near the margin is part of a pattern of increasing mass balance gradients as shown in Fig. $3 b$. A careful analysis shows that the mass balance gradient increases significantly over time. Two years are ignored in this analysis. Both years are more than 2 standard deviations from the mean mass balance gradient over the entire period. It is argued that 1991-1992 is not representative as it was a year with extremely low melt likely related to the Pinatubo eruption affecting climate in many regions, and secondly the last year has been ignored because it is exceptional, as the year 2009-2010 with large melt was followed by a dry winter causing considerable melt in the higher parts of the ablation region due to low albedos (Tedesco et al., 2011). If this increasing mass balance remains a robust feature over time, it implies that the sensitivity of the mass balance increases (Oerlemans, 2001). Given the two exceptions and the limited data, only $21 \mathrm{yr}$, we need to be careful in claiming this.

\subsection{Mass balance as a function of elevation}

Figure 4 presents the surface mass balance as a function of elevation over the ablation area. The average mass balance increases linearly with elevation $(r=0.996$, mean gradient $3.8 \mathrm{~mm}$ w.e. $\mathrm{m} \mathrm{yr}^{-1}$ ). In absolute sense, the variability near the margin is larger than near the equilibrium line, leading to the divergence of the pattern in Fig. 4. During some years, the ablation at Site $7(1110 \mathrm{~m})$ is higher than at Site $6(1010 \mathrm{~m})$, which is likely related to local variations in the albedo of 


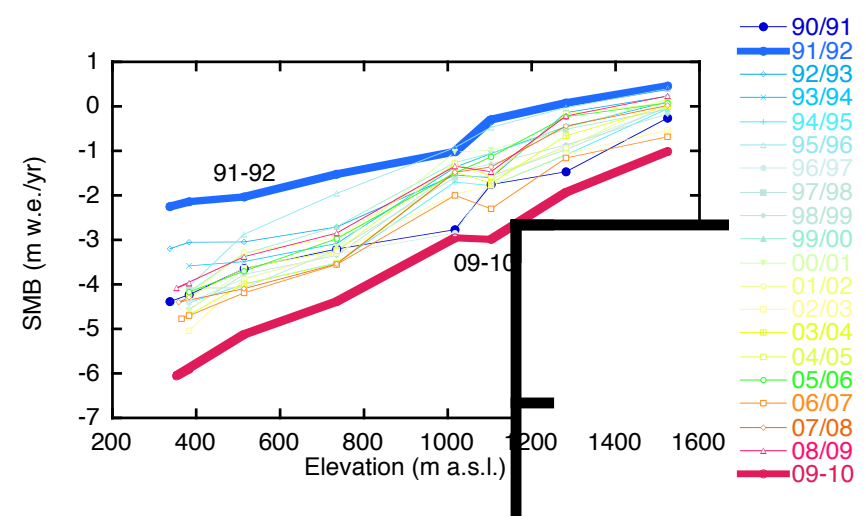

Figure 4. Surface mass balance as a function of elevation for each individual year starting in 1990. The lowest surface mass balance was recorded the second year and the highest during the season 2009-2010; both are indicated with thick lines.

the surface (e.g. Greuell and Knap, 2000 and Wientjes et al., 2011). The highest ablation took place during the season 2009-2010, while the lowest ablation was recorded during the season 1991-1992. The average mass balance gradient is $3.8 \mathrm{~mm}$ w.e. $\mathrm{m} \mathrm{yr}^{-1}$ over the ablation area.

Based on the data close to the equilibrium line (Site 8, Site 9 and Site 10, if available), we calculated for every year the height of the equilibrium line. We included a small correction for height changes due to ice displacement over the course of time. Based on GPS velocities and surface elevation gradients, the varying locations over time are reduced to a standardized height. This height correction is not larger than plus or minus $8 \mathrm{~m}$ in a single year. On average, the equilibrium line altitude is $1553 \mathrm{~m}$ a.s.l., just above Site 9. The yearly values of the equilibrium line height are presented in Fig. 5a. Figure 5b shows the cumulative mass balance at Site 9. The figure indicates that the site is close to the equilibrium line (mean $-0.1 \mathrm{~m}$ w.e. $\mathrm{yr}^{-1}$ ), with a few consecutive negative values at the end of the series.

\section{Conclusions}

We have presented a data set of surface mass balance over a period of $21 \mathrm{yr}$ along a transect in West Greenland. Data can be used for validation of satellite observations and regional climate models both with respect to the interannual variability as well as the mass balance gradient with elevation. Furthermore, data can be used for validation of satellite estimates of equilibrium line altitude or melt extent, both important quantities for assessing changes in the Greenland ice sheet.

Acknowledgements. Many people contributed to the fieldwork over time. In particular, we would like to mention Dirk van As and Alun Hubbard who assisted in the field wherever possible over the last few years. This project was financed over time by
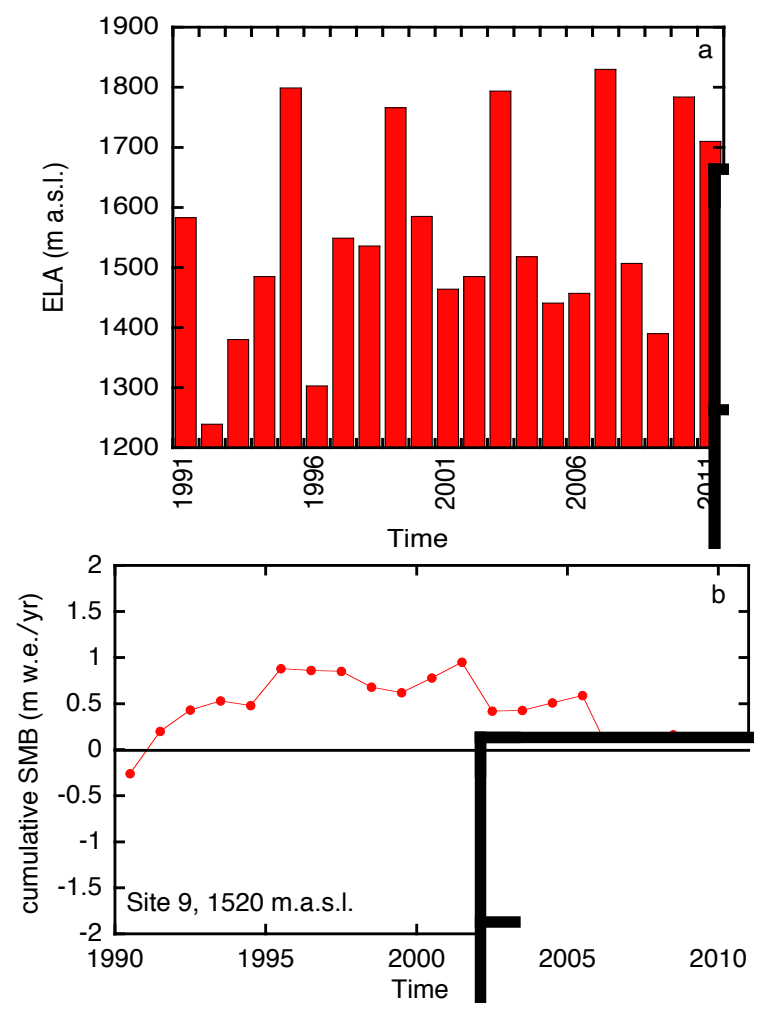

Figure 5. (a) Equilibrium line altitude as a function of time and (b) Cumulative surface mass balance near the equilibrium line indicating an extension of the ablation zone over the last few years.

Utrecht University, and several grants from the Dutch Science foundation including the Spinoza Program and the Netherland Polar Programme. Over the last few years, the project has also been funded by a grant from the Royal Academy of Science (KNAW) to J. Oerlemans. M. Pelto and 2 anonymous reviewers contributed to improving the text of this paper.

Edited by: O. Eisen

\section{References}

Braithwaite, R. J. and Olesen, O. B.: Detection of climate signal by interstake correlations of annual ablation data Qamanânarssûp Sermia, West Greenland, J. Glaciol., 35, 253-259, 1989.

Greuell, J. W. and Knap, W. H.: Remote sensing of the albedo and detection of the slush line on the Greenland ice sheet, J. Geophys. Res., 105, 15567-15576, 2000.

Greuell, J. W., Denby, B., van de Wal, R. S. W., and Oerlemans, J.: Ten years of mass-balance measurements along a transect near Kangerlussuaq, Greenland, J. Glaciol., 47, 157-158, 2001.

Krabill, W., Hanna, E., Huybrechts, P., Abdalati, W., Cappelen, J., Csatho, B., Frederick, E., Manizade, S., Martin, C., Sonntag, J., Swift, R., Thomas, R., and Yungel, J.: Greenland Ice Sheet: Increased coastal thinning, Geophys. Res. Lett., 31, L24402, doi:10.1029/2004GL021533, 2004.

Oerlemans, J.: Glaciers and Climate Change, A.A. Balkema Publishers, 148 pp., ISBN 9026518137, 2001. 
Reeh, N.: Parameterization of melt rate and surface temperature on the Greenland Ice Sheet, Polarforschung, 59, 113-128, 1991.

Rignot, E. and Kanagaratnam, P.: Changes in the velocity structure of the Greenland Ice Sheet, Science, 311, 986-990, doi:10.1126/science.1121381, 2006.

Sørensen, L. S., Simonsen, S. B., Nielsen, K., Lucas-Picher, P., Spada, G., Adalgeirsdottir, G., Forsberg, R., and Hvidberg, C. S.: Mass balance of the Greenland ice sheet (2003-2008) from ICESat data - the impact of interpolation, sampling and firn density, The Cryosphere, 5, 173-186, doi:10.5194/tc-5-173-2011, 2011.

Tedesco, M., Fettweis, X., van den Broeke, M. R., van de Wal, R. S. W., Smeets, C. J. P. P., van de Berg, W. J., Serreze, M. C., and Box, J.: The role of albedo and accumulation in the 2010 melting record in Greenland, Environ. Res. Lett., 6, 014005, doi:10.1088/1748-9326/6/1/014005, 2011.

Thomas, R., Davis, C., Frederick, E., Krabill, W., Li, Y., Manizade, S., and Martin, C.: A comparison of Greenland ice-sheet volume changes derived from altimetry measurements, J. Glaciology, 54, 203-212, 2008.

Thomsen, H. H.: Continued glaciological work northeast of Jakobshavn, West Greenland, Grønlands Geol. Unders. Rep., 135, 8487, 1987.

Van As, D., Fausto, R. S., and the PROMICE project team: Programme for Monitoring of the Greenland Ice Sheet (PROMICE): first temperature and ablation records, Geol. Surv. Den. Greenl., 23, 73-76, 2011.

Van de Wal, R. S. W., Bintanja, R., Boot, W., van den Broeke, M. R., Conrads, L. A., Duynkerke, P. G., Fortuin, J. P. F., Henneken, E. A. C., Knap, W. H., Oerlemans, J., Portanger, M. J., and Vugts, H. F.: Mass balance measurements in the Søndre Strømfjord area in the period 1990-1994, Z. fur Gletscherkd. und Glazialgeol., 31, 57-63, 1996.

Van de Wal, R. S. W., Greuell, W., van den Broeke, M. R., Reijmer, C. H., and Oerlemans, J.: Mass balance measurements along a transect in West-Greenland over the period 1990-2003, Ann. Glaciol., 42, 311-316, 2005.
Van den Broeke, M. R., Smeets, C. J. P. P., Ettema, J., and KuipersMunneke, P.: Surface radiation balance in the ablation zone of the west Greenland ice sheet, J. Geophys. Res., 113, D13105, doi:10.1029/2007JD009283, 2008a.

Van den Broeke, M. R., Smeets, C. J. P. P., and Ettema, J.: Surface layer climate and turbulent exchange in the ablation zone of the west Greenland ice sheet, Int. J. Climatol., 29, 2309-2323, doi:10.1002/joc.1815, 2008b.

Van den Broeke, M. R., Bamber, J., Ettema, J., Rignot, E., Schrama, E., van de Berg, W. J., van Meijgaard, E., Velicogna, I., and Wouters, B.: Partitioning recent Greenland mass loss, Science 326, 984-986, 2009.

Van den Broeke, M. R., Smeets, C. J. P. P., and van de Wal, R. S. W.: The seasonal cycle and interannual variability of surface energy balance and melt in the ablation zone of the west Greenland ice sheet, The Cryosphere, 5, 377-390, doi:10.5194/tc-5-377-2011, 2011.

Wientjes, I. G. M. and Oerlemans, J.: An explanation for the dark region in the western melt zone of the Greenland ice sheet, The Cryosphere, 4, 261-268, doi:10.5194/tc-4-261-2010, 2010.

Wientjes, I. G. M., Van de Wal, R. S. W., Reichart, G. J., Sluijs, A., and Oerlemans, J.: Dust from the dark region in the western ablation zone of the Greenland ice sheet, The Cryosphere, 5, 589-601, doi:10.5194/tc-5-589-2011, 2011.

Wouters, B., Chambers, D., and Schrama, E. J. O.: GRACE observes small-scale mass loss in Greenland, Geophys. Res. Lett., 35, L20501, doi:10.1029/2008GL034816, 2008.

Zwally, H. J., Li, J., Brenner, A. C., Beckley, M., Cornejo, H. G., DiMarzio, J., Giovinetto, M. B., Neumann, T., Robbins, J., Saba, J. L., Yi, D., and Wang, W.: Greenland ice sheet mass balance: distribution of increased mass loss with climate warming; 200307 versus 1992-2002, J. Glaciol., 57, 88-102, 2011. 